\title{
ON THE SENSITIVITY OF ECOLOGICAL ECONOMICS MODELS OF LAKE WATER RESOURCE MANAGEMENT TO THE WELFARE FUNCTION PARAMETERS
}

\author{
D. V. Kovalevsky \\ Nansen International Environmental and Remote Sensing Centre (NIERSC), \\ Saint Petersburg State University
}

\begin{abstract}
A generalized version of the shallow lake economics model, built upon the initial version of the model as described in a seminal paper by Mäler et al. (2003) was developed and analyzed. The model is able to simulate the coupled economic-ecological dynamics under the conditions of pronounced nonlinearity of the ecological (lake) module leading to hysteresis effects and irreversibility for certain values of model parameters. The decisionmaking in the area of lake water management is parameterized by the social welfare function consisting of two terms: the utility originating from the economic activity in the lake surroundings (increasing with the anthropogenic loading on the lake), and the disutility originating from the pollution of the lake (increasing with the pollution level). From the economic side, the problem is therefore to find a tradeoff between the level of economic activity in the lake surroundings and the pollution level. In the basic version of the model, the disutility related to pollution is quadratic in phosphorous concentration. This quadratic disutility is replaced with a more general power law, and the sensitivity of the generalized model to its exponent is explored. The numerical analysis performed suggests that the generalized model is quantitatively sensitive to varying the value of the exponent, yet structurally robust.
\end{abstract}

Ke y w ord s: lake pollution dynamics; nonlinearity; hysteresis; anthropogenic loading; mathematical economics; optimal control.

\section{Д. В. КоваЛОвскИй. О ЧУВСТВИТЕЛЬНОСТИ ЭКОЛОГО-ЭКОНОМИ- ЧЕСКИХ МОДЕЛЕЙ УПРАВЛЕНИЯ ВОДНЫМИ РЕСУРСАМИ ОЗЕР К ПАРАМЕТРАМ ФУНКЦИИ БЛАГОСОСТОЯНИЯ}

Разработана и проанализирована обобщенная версия модели экономики мелких озер, основой для которой послужила модель, описанная в пионерной работе Mäler et al. (2003). Модель состоит из двух взаимосвязанных модулей - экономического и экологического (озерного). Последний задан в форме нелинейной динамической модели, связывающей изменение концентрации фосфора в озере с внешней (в том числе антропогенной) нагрузкой. Модель способна воспроизводить динамику объединенной эколого-экономической системы в условиях сильной нелинейности экологического модуля, при определенных значениях параметров модели приводящей к гистерезисным эффектам и необратимости. Принятие решений в области управления водными ресурсами озера формализуется путем введения функции благосостояния, включающей в себя полезность, обусловленную высоким уровнем экономической активности на водосборе (растущую с ростом антропо- 
генной нагрузки на озеро), а также негативные эффекты, вызванные загрязнением озера (усиливающиеся с ростом уровня загрязнения). С экономической точки зрения задача сводится к нахождению оптимального компромисса между ростом экономической активности и усилением загрязнения озера. В исходной версии модели указанные негативные эффекты предполагаются квадратичными по концентрации фосфора в озере. В настоящей работе в статическом случае выполнен анализ обобщенной версии модели, в которой указанная квадратичная зависимость заменена более общей степенной зависимостью с произвольным показателем. Выполненные численные расчеты свидетельствуют о том, что обобщенная модель, будучи чувствительной к значению показателя степени на количественном уровне, остается тем не менее структурно устойчивой при варьировании данного значения.

Ключевые слова: динамика загрязнения озера; нелинейность; гистерезис; антропогенная нагрузка; экономико-математические методы; оптимальное управление.

\section{Introduction}

Modeling of lake dynamics, human impacts on lake ecosystems, and elaboration of model-based scenarios of sustainable water management in catchments has remarkably advanced in recent decades [Astrakhantsev et al., 2003; Menshutkin et al., 2014; Rukhovets and Filatov, 2010, 2014]. Natural scientists develop detailed, realistic models with fine spatial resolution, incorporating the description of numerous complex processes evolving in lakes and lake ecosystems. However, despite all these impressive advances, there is still room for simple models in this research area. Economic-ecological models of lake water management, where both the economic and the ecological modules of the coupled model are often highly stylized, are able to generate surprisingly rich and versatile dynamics, and also to supply decision-makers in the area of sustainable water resource management with non-trivial policy relevant information.

Particularly, a new research area known as "economics of shallow lakes" has evolved recently within the domain of ecological economics [Mäler et al., 2003; Moghayer, 2012; Moghayer and Wagener, 2012; Wagener, 2013]. The present paper is devoted to the analysis of a generalized version of the shallow lake economics model, built upon the 'canonical' version of the model as described in a seminal paper by Mäler et al. [2003].

It should be noted from the very beginning that, in the author's opinion, the adjective 'shallow' in the term "economics of shallow lakes" should in no way be regarded as a 'keyword'. Instead, already in the pioneering paper by Mäler et al. [2003] cited above, the authors express their firm belief that "... it can be expected that the same type of model will be adequate <for deep lakes>" [Mäler et al., 2003, p. 108]. Recent studies provide new supporting evidence to this argument. Particularly, the hysteresis effects successfully mimicked by the shallow lake model (Sec. 2 below) - probably, the most interesting feature of the modelling framework presented below - are apparently relevant not for shallow lakes only, but also for certain deep lakes, e. g. the Lake Ladoga [Pozdnyakov et al., 2013].

The rest of the paper is structured as follows. The ecological module of the shallow lake economics model is described in Sec. 2, while the economic module of the same model is outlined in Sec. 3. In Sec. 4, a generalized shallow lake economics model is presented and analyzed in a static case. Particularly, the sensitivity of the model to the specification of social welfare is estimated numerically. Sec. 5 concludes.

\section{Phosphorous concentration dynamics in a shallow lake}

Following Carpenter and Cottingham [1997] and Scheffer [2004], Mäler et al. [2003] model the dynamics of the eutrophication process in a shallow lake by an ordinary differential equation of the form

$$
\dot{P}(t)=L(t)-\xi P(t)+r \frac{P^{2}(t)}{P^{2}(t)+m^{2}}, P(0)=P_{0},
$$

where $P(t)$ is the amount of phosphorous in algae, $L(t)$ is the loading (i. e. the input of phosphorous), including the anthropogenic fraction, $\xi$ is the rate of loss caused by sedimentation, outflow and sequestration in other biomass, $r$ is the maximum rate of internal loading, and $m$ is the anoxic level. Note that $\xi, r$, and $m$ are constant, while the loading $L(t)$ is generally time-dependent. Hereinafter, the dot over a variable denotes the time derivative. For a brief non-technical discussion of ecological processes in shallow lakes mimicked by Eq. (1) see [Wagener, 2013, Sec. 2.1].

By introducing non-dimensional variables

$$
s(t)=\frac{P(t)}{m},
$$




$$
a(t)=\frac{L(t)}{r},
$$

a non-dimensional lake parameter

$$
b=\frac{\xi m}{r},
$$

and the non-dimensional time

$$
t^{\prime}=\frac{r t}{m}
$$

(the prime in Eq. (5) will be omitted below), we rewrite Eq. (1) in a non-dimensional form

$$
\dot{s}=a(t)-g(s), s(0)=s_{0},
$$

where an auxiliary function $g(s)$ is introduced:

$$
g(s)=b s-\frac{s^{2}}{1+s^{2}} \text {. }
$$

Dependent on the value of the lake parameter $b$, a simple dynamic model (6)-(7) can demonstrate pronounced nonlinearity, hysteresis effects, and irreversibility ${ }^{1}$.

Suppose that the non-dimensional loading $a(t)$ is constant over time: $a(t)=a=$ const. Then, according to Eqs. (6)-(7), the non-dimensional phosphorous concentration $s(t)$ will asymptotically converge to a steady state where

$$
a=g(s) \text {. }
$$

If there are multiple steady states, the particular steady state to which the concentration converges may depend on the initial condition $s_{0}$.

The curve $a=g(s)$ is called the response curve of the system. Three response curves corresponding to three different values of the lake parameter $b(b=0.48 ; 0.50 ; 0.52)$ are shown in Figure 1.

It is easy to prove that in the case of $b \geqslant 3 \sqrt{3} / 8 \quad(b \geqslant 0.65$; case not shown in Figure 1$)$ there is one and only one steady state for every value of $a$.

If $1 / 2<b<3 \sqrt{3} / 8 \quad(0.5<b<0.65)$, we have the reversible case and the hysteresis effect (see the light gray curve in Figure 1 corresponding to $b=0.52$ ). For a certain range of loading, there are now three steady states. Two of them (designated as solid parts of the curve) are stable (referred to as low pollution (LP) steady state and high pollution (HP) steady state below), while the third one (marked as a dashed part of the curve) is unstable.

1 It should be mentioned that research questions related to nonlinearity, thresholds and irreversibility in coupled economicenvironmental models in the presence of environmental tipping points go well beyond the particular research area of economics of shallow lakes and are also highly relevant to other areas of environmental/ecological economics, notably the economics of climate change [Arto et al., 2013].

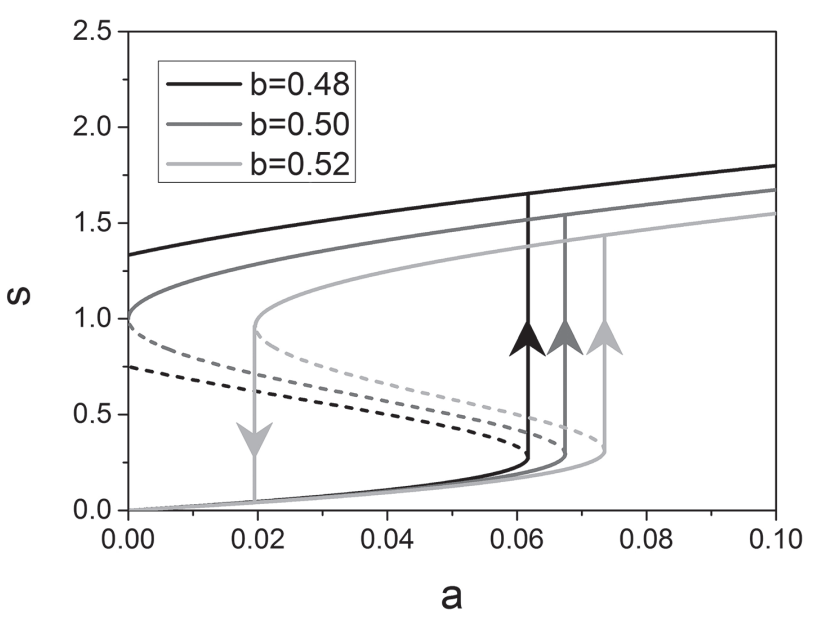

Fig. 1. The response curves of the shallow lake model for three values of the lake parameter $b$ : the light gray curve - reversible case $(b=0.52)$; the black curve irreversible case $(b=0.48)$; the gray curve - threshold case $(b=0.50)$. Solid curves: stable steady states. Dashed curves: unstable steady states. Horizontal axis: loading (a). Vertical axis: phosphorous concentration (s). See details in Sec. 2

Suppose that initially there is no loading $(a=0)$ and no phosphorous in the lake $(s=0)$, but then the loading starts increasing very slowly (quasi-stationary). Until a tipping point is reached, the phosphorous concentration will gradually increase along the LP branch of the light gray response curve. Then, at the tipping point, the lake will rapidly move to a HP state (light gray vertical line with an upward arrow). Suppose, then, that immediately after that the loading starts decreasing slowly. Then the concentration starts decreasing, too, along the HP branch of the light gray response curve, until another tipping point is reached, and the lake rapidly moves to a LP state (light gray vertical line with a downward arrow). This is a manifestation of the pronounced nonlinearity of the system and the hysteresis effect in the lake. Still, the lake dynamics is reversible, although profoundly nonlinear.

If $0<b<1 / 2(0<b<0.5)$, we have the irreversible case of the lake dynamics (see the black curve in Figure 1 corresponding to $b=0.48$ ): if the lake is in a HP state it is trapped there and will never return to a LP state.

Finally, $b=1 / 2(b=0.5)$ is the threshold value of the lake parameter separating reversible cases from irreversible ones (see the gray curve in Figure 1 corresponding to $b=0.50$ ).

\section{Shallow lake economics}

In a shallow lake economics model [Mäler et al., 2003; Wagener, 2013] the social welfare stream $W(a, s)$ is defined as

$$
W=U_{A}-D_{E}
$$


where

$$
U_{A}=\ln a
$$

is the utility originating from the economic activity in the lake surroundings (higher loading implies higher level of economic, notably agricultural, activity), while

$$
D_{E}=c s^{2}
$$

is the disutility originating from the pollution of the lake. The parameter $c$ in Eq. (11) is the measure of economic costs of lake pollution.

In essence, the problem of the economics of shallow lakes defined by Eqs. (9)-(11) is to find a tradeoff between the level of economic activity in the lake surroundings and the level of lake pollution. From mathematical standpoint, the respective problem can be posed (and solved) at various levels of complexity.

The simplest model setup is the static analysis: provided the response curve $a=g(s)$ relating the static loading and the corresponding steady state $(-s)$ is known, to find the 'optimal' value of loading (and hence of the phosphorous concentration) maximizing the welfare (9).

Alternatively, and much in the spirit of the seminal Ramsey - Cass - Koopmans model of economic growth [Barro and Sala-i-Martin, 2003], a dynamic optimization problem can be posed: to maximize the discounted welfare

$$
\bar{W}=\int_{0}^{+\infty} W(a(t), s(t)) \exp (-\rho t) d t
$$

where $\rho$ is the discount rate, $W(a(t), s(t))$ is defined by Eqs. (9)-(11), and $s(t)$ depends on $a(t)$ through the dynamic model (6)-(7).

As Wagener [2013] notes, if in Eq. (12) we adopt the value $\rho=0$ for the discount rate (the choice advocated by Ramsey himself in his pioneering paper [Ramsey, 1928]), the optimal solutions of the dynamic optimization problem (12) will converge to those of the static case.

Finally, if the lake is controlled by several polluters, the shallow lake economics problem can be reformulated in various game-theoretical settings.

\section{On the sensitivity of the shallow lake economics model to welfare specification}

A fundamental question important for nearly all mathematical models of real-world phenomena is to what extent the model is robust with respect to modelling assumptions.

In the present paper, this question is discussed with respect to the shallow lake economics model described in Secs. 2-3. Particularly, the sensitivity of the model to the specification of social welfare is explored (Eqs. (9)-(11)).
As discussed in Sec. 3, in the 'canonical' shallow lake economics model [Mäler et al., 2003; Wagener, 2013] the social welfare $W(\mathrm{Eq}$. (9)) consists of two terms: the utility $U_{A}$ logarithmic in loading (Eq. (10)) and the disutility $D_{E}$ quadratic in pollution (Eq. (11)). It should be noted that the structure of $U_{A}$ and $D_{E}$ in the 'canonical' model is, in fact, purely heuristic, and, to a large extent, the choice of the structural form for $U_{A}$ and $D_{E}$ is made on the ground of tractability of the resultant model.

For instance, logarithmic utilities (like $U_{A}$ in Eq. (10)) are indeed quite popular in many models of mathematical economics (specifically in economic growth theory); however, a number of 'competing' utility specifications does exist that are at least as popular as the logarithmic utility (cf. [Barro and Sala-i-Martin, 2003]). Similarly, the quadratic dependence of disutility $D_{E}$ on pollution (Eq. (11)) is an ad hoc assumption.

So the question is: how will the shallow lake economics model change if we modify the specification of welfare, hence changing the assumptions about the values of decision-makers and the mechanisms of decision-making?

In the present section, we address this question by conducting numerical experiments with a generalized static shallow lake economics model (Sec. 3) where the quadratic dependence of disutility $D_{E}$ on pollution (Eq. (11)) is replaced with a more general power law:

$$
D_{E}^{(\beta)}=C S^{\beta}
$$

(note that in the 'canonical' shallow lake economics model $\beta=2$ ).

As follows from the analysis presented in Secs. 2-3, the 'canonical' static shallow lake economics model is essentially defined by numeric values of two non-dimensional parameters, namely, the lake parameter $b$ (Eq. (4)) appearing in the response function, and the pollution cost parameter $c$ appearing in disutility $D_{E}$ (Eqs. (11) and (13)). With modified disutility $D_{E}^{(\beta)}$, now dependent on $\beta$ (Eq. (13)), the parameter $\beta$ becomes the third key model parameter.

Figure 2, a-d, presents the phase diagrams in the parameter space $b-c$ for the generalized static shallow lake economics model with $\beta=1.0 ; 1.5$; 2.0; and 3.0, respectively. For each phase diagram, the horizontal axis corresponds to the lake parameter $b$, while the vertical axis corresponds to the pollution cost parameter $c$. The parameter space is split into four domains labeled as 1MAX, LP, HP, and IS, respectively.

The 1MAX domain corresponds to the case where the social welfare as a function of loading has a single local maximum, which is also the global maximum. 
a)

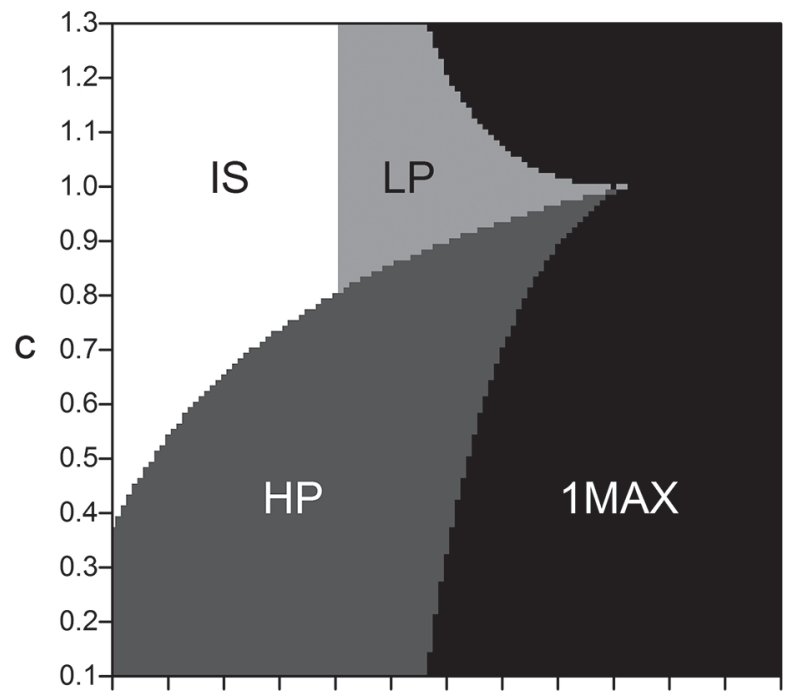

$\begin{array}{lllllllllllll}0.1 & 0.2 & 0.3 & 0.4 & 0.5 & 0.6 & 0.7 & 0.8 & 0.9 & 1.0 & 1.1 & 1.2 & 1.3\end{array}$

$\mathrm{b}$

c)

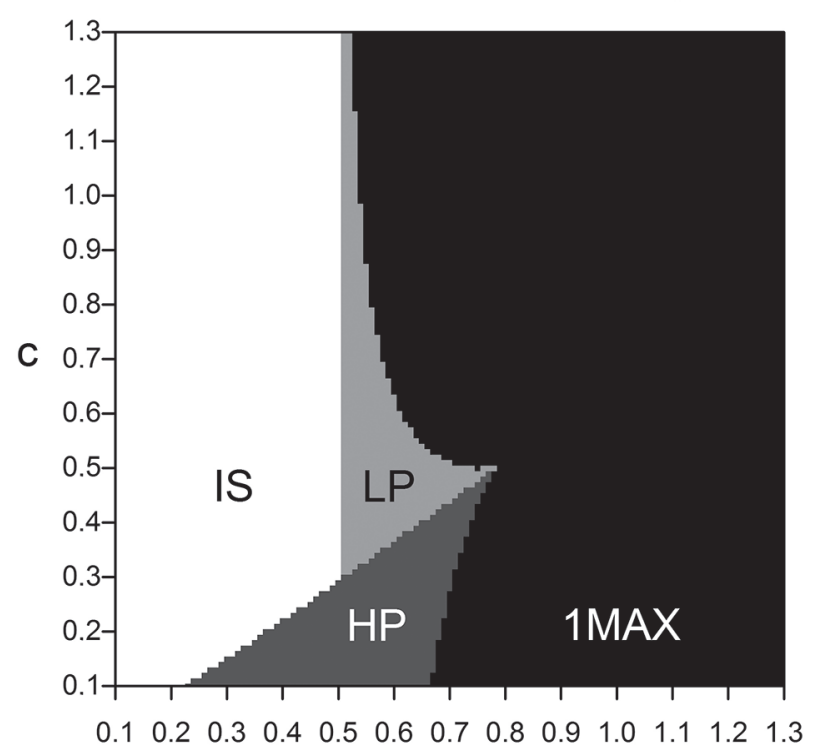

b b) $\beta=1.5$

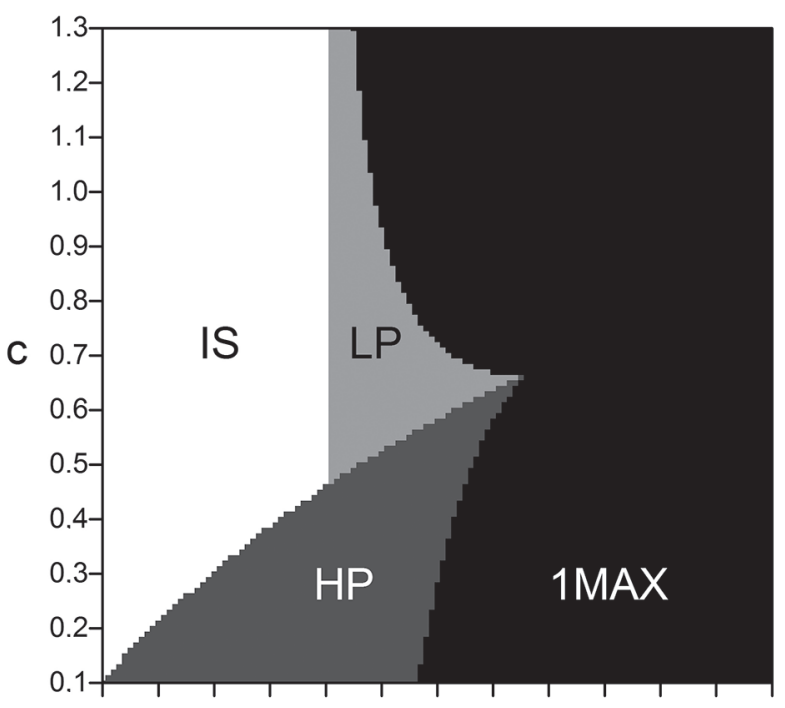

$\begin{array}{lllllllllllll}0.1 & 0.2 & 0.3 & 0.4 & 0.5 & 0.6 & 0.7 & 0.8 & 0.9 & 1.0 & 1.1 & 1.2 & 1.3\end{array}$

b

d)

$\beta=3.0$

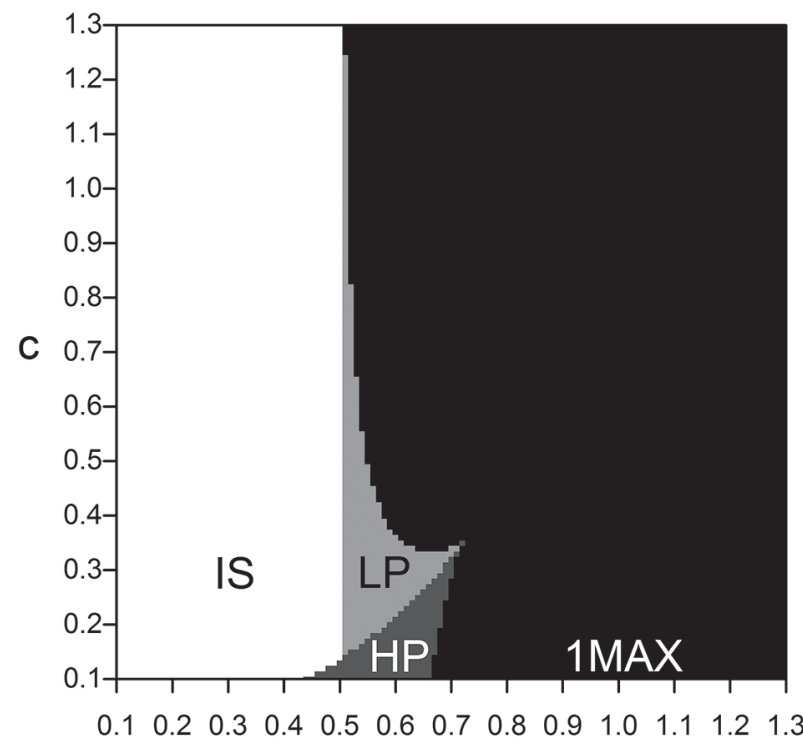

b

Fig. 2. The phase diagrams for the generalized static shallow lake economics model for four different values of the disutility exponent $\beta$ : a) $\beta=1.0$; b) $\beta=1.5$; c) $\beta=2.0$; d) $\beta=3.0$. Horizontal axis: the lake parameter $(b)$. Vertical axis: the pollution cost parameter $(c)$. The labels of the domains on phase diagrams (1MAX, LP, HP, IS) are explained in Sec. 4

In the LP and HP domains, there are two separate local maxima. In the LP domain, the low pollution maximum is the global one, while in the HP domain, the high pollution maximum is the global one.

Finally, in the IS domain the optimal loading depends on the initial state of the system. In fact, in the IS domain the low pollution maximum is higher than the high pollution one, just like in the LP do- main. However, in the IS domain $b<0.5$, so the lake dynamics is irreversible (Sec. 2). Hence, dependent on the initial state, this low pollution maximum might, unfortunately, be unreachable.

As follows from Figure 2, for different values of parameter $\beta$ the positions of boundaries of the domains on phase diagrams are quantitatively different; yet, in all cases considered the phase diagram 
is qualitatively the same. Therefore, we come to a conclusion that the generalized static shallow lake economics model considered in the present section is quantitatively sensitive to varying the value of parameter $\beta$ in Eq. (13), yet structurally robust.

\section{Conclusions}

In this paper, we have presented the first results of the analysis of a generalized shallow lake economics model built upon the seminal model by Mäler et al. [2003]. As discussed in Sec. 4, the specification of the social welfare in the initial version of the model [Mäler et al., 2003] was to a large extent made on an ad hoc basis. At the same time, it is precisely the welfare specification that represents the values and preferences of decisionmakers, and hence the mechanisms of decisionmaking, in the 'canonical' shallow lake economics modelling framework.

The social welfare stream, as defined above, consists of two terms: the utility originating from the economic activity in the lake surroundings, and the disutility originating from the pollution of the lake. The model was generalized here by replacing the disutility quadratic in pollution with a more general power law, and the sensitivity of the generalized model to its exponent was explored. The numerical results presented suggest that the generalized model is quantitatively sensitive to varying the value of the exponent, yet structurally robust.

Other possible modifications of the social welfare can of course be analyzed as well. For instance, the logarithmic utility might be replaced with a power law; also, a multiplicative form of welfare function might be considered instead of an additive form. This analysis is, however, left for further research.

The author is grateful to D. V. Pozdnyakov for helpful comments. The research leading to the reported results has received funding from the European Community's Seventh Framework Programme under Grant Agreement No. 308601 (COMPLEX).

\section{References}

Arto I., Capellán-Pérez I., Filatova T., GonzálezEguino M., Hasselmann K., Kovalevsky D. V., Markandya A., Moghayer S. M., Tariku M. B. Review of existing literature on methodologies to model non-linearity, thresholds and irreversibility in high-impact climate change events in the presence of environmental tipping points. EU FP7 COMPLEX Report D5.2. 31 December 2013. URL: http://owsgip.itc.utwente.nl/projects/complex/complex files/COMPLEX Report D52 2013\%20 31\%2012.pdf (accessed: 17.08.2016).
Astrakhantsev G. P., Menshutkin V. V., Petrova N. A., Rukhovets L. A. Modelirovanie ekosistem bol'shikh stratifitsirovannykh ozer [Modeling ecosystems of large stratified lakes]. St. Petersburg: Nauka, 2003. 363 p.

Barro R. Dzh., Sala-i-Martin Kh. Economic Growth. $2^{\text {nd }}$ edition. Cambridge: The MIT Press, 2003. 672 p.

Carpenter S. R., Cottingham K. L. Resilience and restoration of lakes. Conservation Ecology. 1997. Vol. 1, iss. 1. P. 2. URL: http://www.consecol.org/vol1/ iss1/art2/ (accessed: 17.08.2016).

Menshutkin V. V., Rukhovets L. A., Filatov N. N. Matematicheskie modeli vodnykh ekosistem $v$ zadachakh upravleniya resursami ozer [Mathematical models of water ecosystems in lake resource management problems]. Vodnoe khozyaistvo Rossii [Water Economy of Russia]. 2014. No. 3. P. 100-107.

Moghayer S., Wagener F. O. O. Bifurcations of indifference points in the discrete time lake pollution management problem. European Association of Environmental and Resource Economists. 19 $9^{\text {th }}$ Annual Conference, 27-30 June 2012, Prague. URL: http://www.webmeets. com/files/papers/EAERE/2012/1028/Lake\%20Bifurcation_EAERE_2012.pdf (accessed: 17.08.2016).

Moghayer S. M. Bifurcations of indifference points in discrete time optimal control problems. PhD thesis. Faculty of Economics and Business, Amsterdam School of Economics Research Institute (ASE-RI). Tinbergen Institute Research Series No. 525. 2012. 136 p. URL: http://hdl.handle.net/11245/1.370551 (accessed: 17.08.2016).

Mäler K.-G., Xepapadeas A., de Zeeuw A. J. The economics of shallow lakes. Environmental and Resource Economics. 2003. Vol. 26, iss. 4. P. 603-624. doi: 10.1023/B:EARE.0000007351.99227.42

Pozdnyakov D. V., Korosov A. A., Petrova N. A., Grassl $H$. Multi-year satellite observations of Lake Ladoga's biogeochemical dynamics in relation to the lake's trophic status. Journal of Great Lakes Research. 2013. Vol. 39, Supplement 1. P. 34-45. doi: 10.1016/ j.jglr.2013.05.002

Ramsey F. P. A mathematical theory of saving. The Economic Journal. 1928. Vol. 38, iss. 152. P. 543-559.

Rukhovets L., Filatov N. (Eds) Ladoga and Onego Great European Lakes. Observations and Modelling. Springer-Verlag Berlin Heidelberg. 2010. 308 p. doi: 10.1007/978-3-540-68145-8

Rukhovets L. A., Filatov N. N. Ozera i klimat: modeli i metody [Lakes and climate: models and methods]. Modeli i metody v probleme vzaimodeistviya atmosfery i gidrosfery [Models and methods in atmosphere/hydrosphere interaction]. Eds V. P. Dymnikov, V. N. Lykosov, E. P. Gordov. Tomsk: Izdatel'skii Dom TGU, 2014. 524 p.

Scheffer M. Ecology of Shallow Lakes. Population and Community Biology Series, Vol. 22. Springer Netherlands. 2004. 357 p. doi: 10.1007/978-1-4020-3154-0

Wagener $F$. Shallow lake economics run deep: nonlinear aspects of an economic-ecological interest conflict. Computational Management Science. 2013. Vol. 10, iss. 4. P. 423-450. doi: 10.1007/s10287-013-0191-5

Received July 29, 2016 


\section{СВЕДЕНИЯ ОБ АВТОРЕ:}

\section{Ковалевский Дмитрий Валерьевич}

старший научный сотрудник, к. Ф.-М. н.

Международный центр по окружающей среде

и дистанционному зондированию им. Нансена

(Фонд «Нансен-центр»)

14-я линия В. О., 7, оф. 49, Санкт-Петербург,

Россия, 199034

Санкт-Петербургский государственный университет Университетская наб., 7-9, Санкт-Петербург,

Россия, 199034

эл. почта: d_v_kovalevsky@list.ru,

dmitry.kovalevsky@niersc.spb.ru

тел.: +7 (812) 3245103

\section{CONTRIBUTOR:}

\section{Kovalevsky, Dmitry}

Nansen International Environmental and Remote Sensing Centre (NIERSC)

14th Line 7, office 49, Vasilievsky Island, 199034

St. Petersburg, Russia

Saint Petersburg State University

7-9 Universitetskaya Emb., 199034

St. Petersburg, Russia

e-mail: d_v_kovalevsky@list.ru,

dmitry.kovalevsky@niersc.spb.ru

tel.: +7 (812) 3245103 